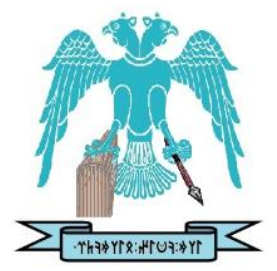

JOURNAL OF ENERGY SYSTEMS

$2020,4(1)$

\title{
Photovoltaic geographical information system module for the estimation of solar electricity generation: A comparative study in Khyber Pakhtunkhwa Pakistan
}

\author{
Sapna Tajbar \\ Shaheed Benazir Bhutto Women University, Department of Physics, Peshawar, Pakistan, sapnatajbar@gmail.com \\ Lubna Rafiq iD \\ University of Salzburg, Department of Geoinformation, Salzburg, Austria, lubna.rafiq@stud.sbg.ac.at \\ Sahar Bibi \\ National University of Sciences and Technology, Department of Electrical Engineering, Islamabad, Pakistan, \\ sehar1520@gmail.com
}

Maha Saidullah iD

Shaheed Benazir Bhutto Women University, Department of Physics, Peshawar, Pakistan, mahasaidullah246@ gmail.com

$\begin{array}{rr}\text { Submitted: } & 18.02 .2020 \\ \text { Accepted: } & 13.03 .2020 \\ \text { Published: } & 31.03 .2020\end{array}$

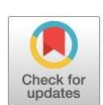

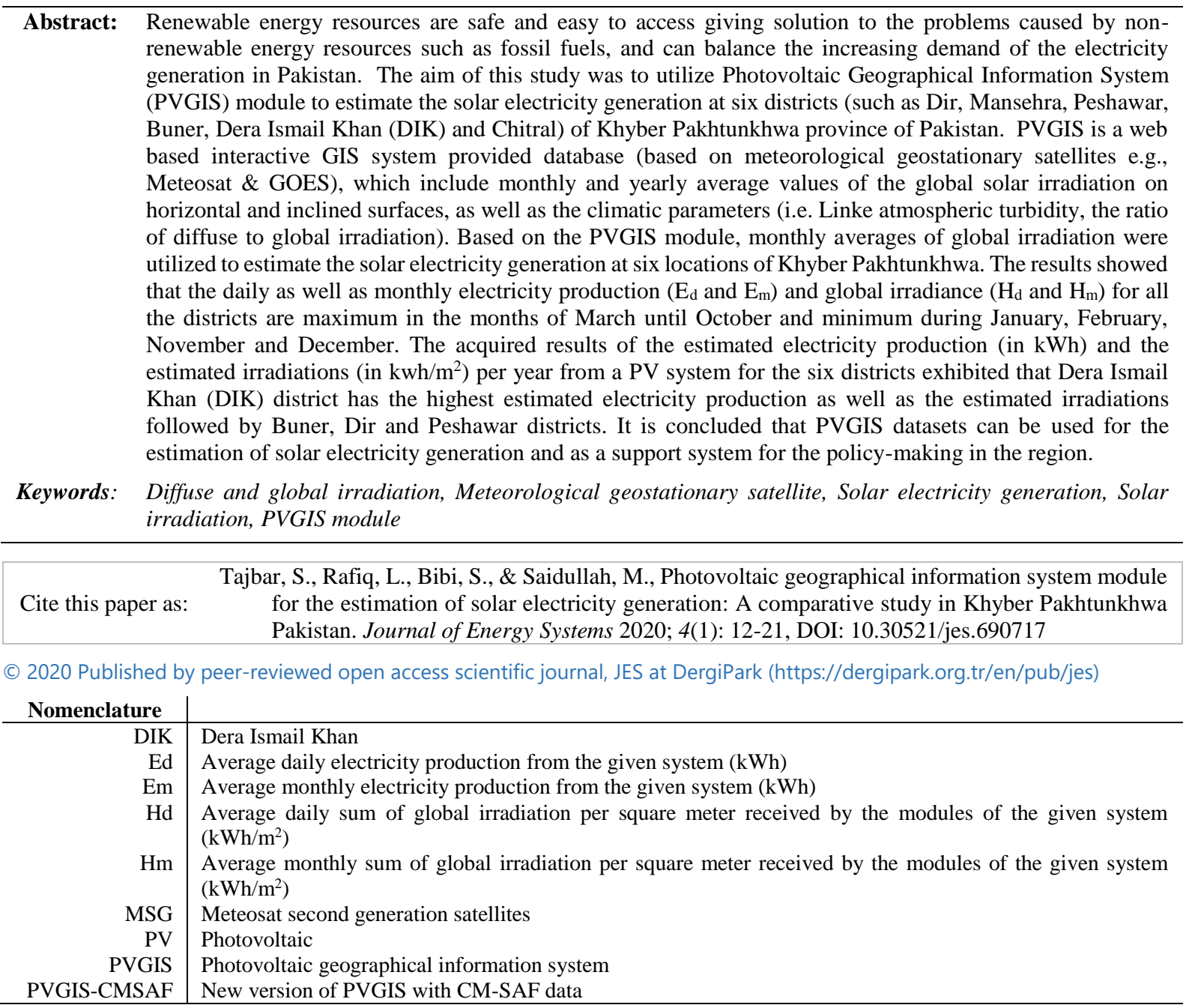




\section{INTRODUCTION}

Solar energy is a potential resource, which is clean, sustainable, and environment friendly among the various renewable energy resources. Solar radiation is an important element for determining the electricity generated by photovoltaic (PV) systems [1]. The investment in PV systems became lucrative in recent years because of its economic and environmental benefits. Worldwide grid-connected PV systems utilization is increasing. The total capacity of the installation of solar photovoltaic systems across the world reached to $135 \mathrm{GW}$ by October 2013, exhibiting growth of $112 \mathrm{GW}$ in the past four years [2].

Pakistan has a great potential of solar power production because it receives an enormous amount of solar radiations throughout the year that keeps its surface warm [3]. It receives $2 \mathrm{MWh} / \mathrm{m}^{2}$ solar irradiation and sunshine hours of 1500 - 3000 each year [4]. About 2900000 MW solar energy potential is approximate in Pakistan [5]. Unfortunately, we have not been able to make full use of solar energy potential in Pakistan because of various factors, for example, the initial expense of solar panels, problems related to maintenance, lack of good policies, awareness and research and development. Welltimed and suitable exploitation of the solar energy resources are required for the country [4].

Climatic ground stations primarily measure the solar radiation data and are sparsely located. To acquire maps, globally different approaches have been used such as interpolation, weighted mean methods, kriging or co-kriging and spline functions. Though the satellite based acquired data provide less accurate values as compared to the ground measurements, but still rapidly developing techniques of measuring the data of solar irradiance are from Meteosat $2^{\text {nd }}$ generation which are meteorological geostationary satellites and up to date processing models (such as Heliosat-3). Maximum spatial and temporal resolution datasets are provided by the satellites because of which they can be utilized for PV monitoring at large scale and weather as well as for the forecasting of energy. The database (spatially distributed map) especially PVGIS module assist in understanding the solar energy resource geographical and time allocation as well as in the prospective performance of the photovoltaic systems [1].

Considering the potential importance of the PVGIS module for the estimation of solar electricity generation, worldwide numerous studies have been carried out utilizing the PVGIS based module satellite data [1-2, 6-10]. A research was conducted by making use of the PVGIS module in 5 candidate countries and 25 member states of the European Union. The electricity production calculation by current PV technology is a primary step in the assessment for the supply of future energy and logical execution of legitimate and financial frameworks to assist the evolving industrial generation of PV. Three important features were inspected such as the assumed annual mean electricity production of grid connected standard $1 \mathrm{kWp}$ PV system, the theoretical prospective production of PV electricity and calculation of requisite installed capacity for every country to provide at least $1 \%$ of the national electricity utilization from PV system. The assessment indicated that PV is at present contributing towards the mixed renewable energy resources and the expectations are the same in the future for the European Union [7].

In a study, the outcomes of modification of the solar radiation data in the CM-SAF to PVGIS computed from satellite data were presented. This database (CM-SAF) of solar radiation is distinguished by minimum overall bias and at sites of validation indicates the good precision. The addition of this application brings advancements in relation to the databases of solar radiation that are already included in the PVGIS [11]. These types of research studies over the study area (i.e. the Khyber Pakhtunkhwa province) are sparse. Therefore, this study is of potential importance, which for the first time utilizing the datasets of Photovoltaic Geographical Information System (PVGIS) for estimating the solar electricity generation in Khyber Pakhtunkhwa. 
The paper is arranged in the following way: Initially, Section 2.1 generally describes the studied region, Section 2.2 discusses the utilized data and its description and Section 2.3 shows the applied methodology, whereas Section 3 shows the results and discussion along with the conclusions presented in the last section.

\section{STUDY REGION, DATA USED, GENERAL DESCRIPTION AND METHODOLOGY}

\subsection{Study Region}

Khyber Pakhtunkhwa, previously known as North West Frontier province (NWFP) is one of Pakistan's five provinces, which is the country's northern part. Its area is 46296 square kilometers and population is 30523371. To the East and North, it is bounded by Northern areas, to the North and West by country Afghanistan, to the South West by Baluchistan and to the South East side by Punjab. Its climate alters with the elevation [12]. Our study regions are the six districts of Khyber Pakhtunkhwa (i.e. Dir, Chitral, Dera Ismail khan, Peshawar, Mansehra and Buner) as depicted in Figure 1. The Chitral district has a pleasant weather during the summer season, but very harsh during the winter season. The mean annual temperature recorded is $16{ }^{\circ} \mathrm{C}$, minimum average is $8{ }^{\circ} \mathrm{C}$ and maximum reaches to $24{ }^{\circ} \mathrm{C}$. It receives an annual total rainfall of $451 \mathrm{~mm}$ with substantial snowfall during the winter season. The district of Dera Ismail Khan is situated in the arid zone, where summers are extremely hot and winters are mild. The mean annual temperature is $24{ }^{\circ} \mathrm{C}$, with a minimum average temperature of $17{ }^{\circ} \mathrm{C}$ and a maximum of $32{ }^{\circ} \mathrm{C}[13]$.

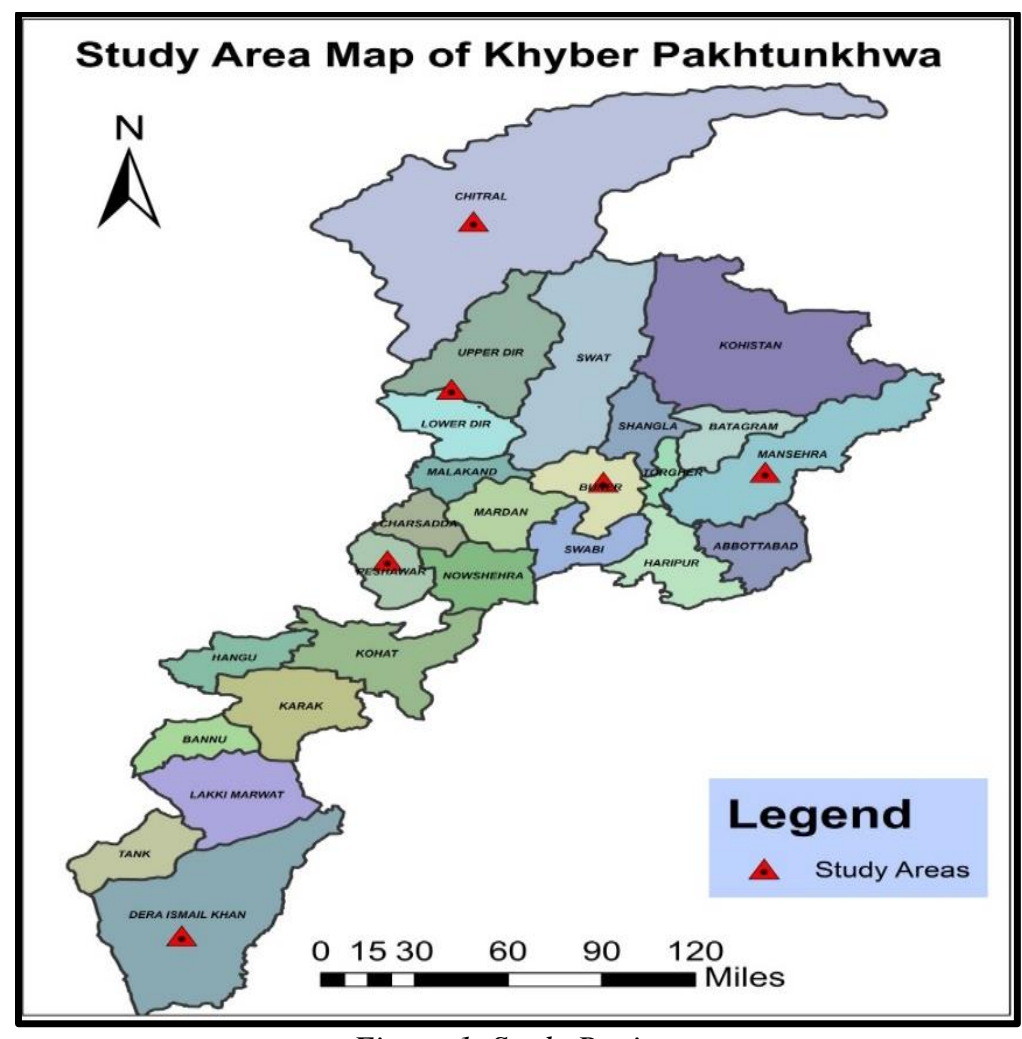

Figure 1. Study Region.

The Mansehra district climate is very cold in the winter and mild warm in the summer season. The mean maximum temperature noted is $35^{\circ} \mathrm{C}$ in the month of June and mean minimum is $2{ }^{\circ} \mathrm{C}$ in January [14]. Lower Dir has hot as well as humid weather during the summer season and mild during the winter season while the upper Dir has pleasant weather in summer and very cold in winter. Dir has $16.9{ }^{\circ} \mathrm{C}$ annual average temperature. During the summer season, Peshawar's average highest temperature is over $40{ }^{\circ} \mathrm{C}$ 
and the lowest is $25{ }^{\circ} \mathrm{C}$ whereas the average lowest temperature within winter is $4{ }^{\circ} \mathrm{C}$ and highest is $18.35{ }^{\circ} \mathrm{C}$ [15]. Dir district's climate is temperate in summer and very harsh during the winter season. For about 7 months of the year, the average temperature in summer remains around $10-15{ }^{\circ} \mathrm{C}$, while during winter it reaches well below the freezing point [16].

\subsection{Utilized Data and its Description}

PVGIS is a common, free-to-use GIS-based calculator, which is online and is implemented by Joint Research Centre from European Commission. To make the estimates of the PV systems performance as well as other calculations, this web-based PVGIS receives the data on solar radiation [17]. Climate-SAF (CM-SAF) provided the extensive database is used by PVGIS software. CM-SAF is the Satellite Application Facility on Climate Monitoring that makes use of data, which is derived from the computations of satellite images [18]. The database provides monthly and yearly mean data on inclined and horizontal surfaces for the global irradiation along with the climatic variables required for the evaluation of the PV electricity production [1]. For the evaluation of electricity production from photovoltaic systems and solar energy resource, it provides a map-based inventory within Europe, South West Asia and Europe [19]. PVGIS give access to four types of calculation tools that are daily radiation tool, PV estimation tool, the monthly radiation tool, and the standalone PV tool [2]. Data sets (such as the mean electricity generation on the daily basis $\left(E_{d}\right)$, mean monthly electricity generation $\left(E_{m}\right)$, mean total global irradiation per square meter on daily basis $\left(H_{d}\right)$ and monthly mean global irradiation per square meter $\left.\left(H_{m}\right)\right)$ for the study are obtained from the PVGIS website http://re.jrc.ec.europa.eu/pvgis/apps4/pvest.php?map=africa\&lang=en.

\subsection{Methodology}

The research utilized solar climatological data sets acquired from PVGIS to investigate the prospective production of solar electricity in the studied area. The adopted methodology is as follows: The mean daily $\left(E_{d}\right)$ and monthly generation of electricity $\left(E_{m}\right)$, the mean sum of global irradiation per square meter on the daily basis $\left(\mathrm{H}_{\mathrm{d}}\right)$ as well as total monthly global irradiation per square meter $\left(\mathrm{H}_{\mathrm{m}}\right)$ acquired data was used for graphs to show daily and monthly variations. The annual average PV estimated electricity production and irradiation estimate histograms were also developed. The PVGIS data base formulas behind the calculation of different parameters are given below:

\subsubsection{Calculation of long-term monthly averages in CMSAF PVGIS database}

Long-term monthly calculation of the means is very complex because of the certainty that not all the hours are present in the dataset. 93.3\% of the hours are present in the dataset of MSG (i.e. Meteosat Second Generation satellites) which is to a smaller extent complete. The month wise computation of means becomes difficult, because the solar radiation quantity during the month may vary methodically when several days are missing in the month. For the minimization of this issue, the averaging is performed in subsequently as the map of global irradiance $\mathrm{G}_{\text {hdmy }}$ should be considered for the hour $h$, day $d$, month $m$ and year $y$. In the first step, year-wise mean is computed;

$$
G h d m=\frac{1}{N} \sum_{y=1}^{N} G h d m y
$$

Whereas $N$ represents the number of years that have hour $h$, day $d$ and month $m$. During this computation, there must be the chance that for some specific years, the data is not available and then the mean is computed over the years that are present.

Next, to acquire the yearly long-term mean irradiation for the month $H_{m}$, each month's hourly values in time are integrated. The integration becomes a single sum, if the irradiation is expressed in $\mathrm{Wh} / \mathrm{m}^{2}$ or $\mathrm{kWh} / \mathrm{m}^{2}$ units. 


$$
H m=\sum_{h=1}^{24} \sum_{d=1}^{D m} G h d m
$$

whereas the days number, within month $m$ is represented by $D_{m}$. Then the mean monthly irradiance is calculated as:

$$
G m=\frac{H m}{24 D m}
$$

and the long-term mean of the total global horizontal irradiation on the yearly basis is measured by the following equation:

$$
\text { Hyear }=\sum_{m=1}^{12} H m
$$

For the direct and global parts of the datasets of MSG, this process has been carried out on an independent basis [18].

\subsubsection{The estimation of PV potential using CMSAF PVGIS database}

The PV-modules performance depends on the temperature and solar irradiation, the estimation of solar electricity was calculation for the crystalline silicon cells-based PV-modules. This application computes the prospective production of electricity $E(\mathrm{kWh})$ of a $\mathrm{PV}$ design with specified modules orientation and inclination on the yearly basis while using the formula:

$$
E=365 P_{k} r_{p} H_{h, i}
$$

Whereas, $P_{k}(\mathrm{~kW})$ represents the peak power that is installed one, the performance ratio of the system $r_{p}$ represents the distinct value 0.75 for the system that is mounted on roof having modules from mono-or polycrystalline silicon and $H_{h, i}$ shows the monthly or yearly mean value of global irradiation on daily basis falling on the inclined or horizontal surface. The calculator can insinuate the PV modules favorable orientation/inclination for gathering the greatest amount of electricity during a year [1].

\subsubsection{PV-Modules installation information}

The PV-modules installation information is given in the following Table 1.

Table 1. Optimal inclination/orientation of PV modules and their estimated losses

\begin{tabular}{ll}
\hline \multicolumn{1}{c}{ Parameter } & \multicolumn{1}{c}{ Value } \\
\hline PV modules mounting position & Free standing \\
PV modules inclination & $33^{\circ}$ \\
Nominal power of the PV system (crystalline silicon) & $1.0 \mathrm{~kW}$ \\
Estimated losses due to temperature and low irradiance & $14.2 \%$ (using local ambient temperature) \\
Estimated loss due to angular reflectance effects & $2.8 \%$ \\
Other losses (cables, inverter etc.) & $14.0 \%$ \\
Combined PV system losses & $28.3 \%$ \\
\hline
\end{tabular}

\section{RESULTS AND DISCUSSION}

Solar power is a universal resource because on the surface of earth, the solar irradiance is equally distributed [20]. Globally, the enormous increase in the installed solar electricity production gives us a fair idea about the potential available in the solar energy for the electricity generation [7]. Pakistan have 
abundant resources of solar energy and is ideal location for the solar energy resources exploitation [3]. This study objective is to estimate the solar electricity generation potential in Khyber Pakhtunkhwa, Pakistan by using PVGIS data. Results from this study are briefly explained below:

\subsection{Average Daily Electricity Production and Global Irradiance}

Figure 2 manifests the average daily generation of electricity $\left(E_{d}\right)$ from the specified system $(\mathrm{kWh})$ and mean total global irradiation per square meter on the daily basis $\left(H_{d}\right)$ acquired by the specified system's modules $\left(\mathrm{kWh} / \mathrm{m}^{2}\right)\left(H_{d}\right)$ for the six districts of Khyber Pakhtunkhwa, Pakistan. The daily electricity production as well as global irradiation for all the districts are recorded as maximum from March until October months and minimum during January, February, November and December. The results are in agreement with the studies carried out for different countries around the world [10,21-28].
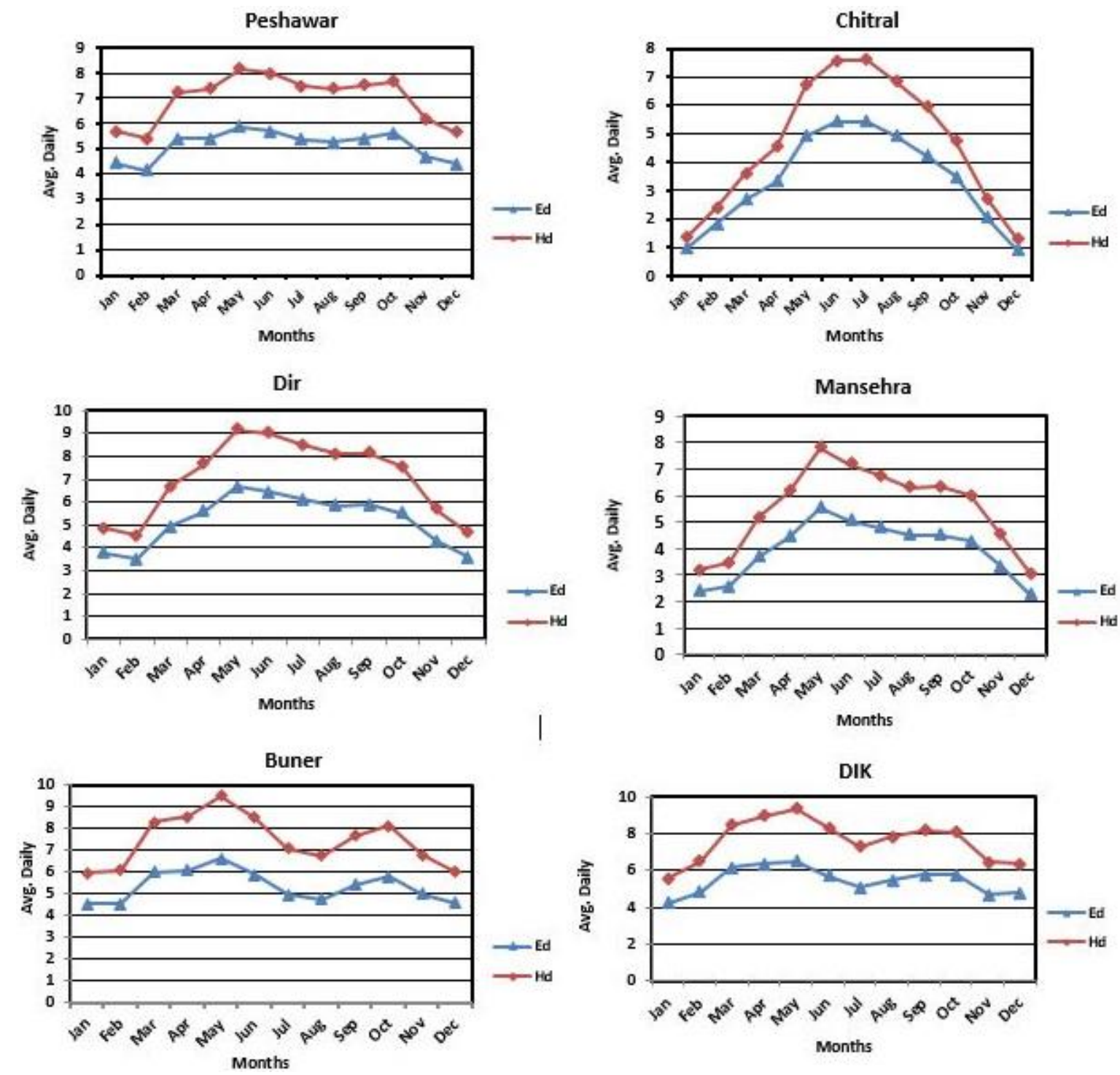

Figure 2. Average daily electricity production $\left(E_{d}\right)$ from the given system $(k W h)$ and average daily sum of global irradiation $\left(H_{d}\right)$ received by the modules of the given system $\left(\mathrm{kwh} / \mathrm{m}^{2}\right)$ for six districts of Khyber Pakhtunkhwa, Pakistan

\subsection{Average Monthly Electricity Production and Global Irradiance}

Figure 3 shows the mean monthly electricity generation $\left(E_{m}\right)$ as well as the monthly mean global irradiation per square meter $\left(H_{m}\right)$ for the six districts of Khyber Pakhtunkhwa. For all the districts, there 
is a steady increase observed in the monthly electricity production as well as global irradiation during the months of March until October and lowest during January, February, November and December. Some more studies have been carried out in Khyber Pakhtunkhwa, Pakistan using different data sources with distinct techniques whose findings were in agreement with our findings [3,25]. A study conducted at Ispara in North Italy, assessed the energy rating of PV modules based on the PVGIS irradiance and temperature database over a 12-month period discussed similar results. Due to unusual rainy weather, the PVIGIS energy prediction values for the poly-Si module were lower in the month of November as compared to the other winter season months. According to this study, the PVGIS while still good, its estimated values were over predicted during some months as compared to the measured and point by point values. Therefore it was concluded that PVGIS prediction is suitable for longer periods such as one year but not appropriate for single months [26]. More studies around the world discussed similar results $[2,9-10,20,27-29]$.
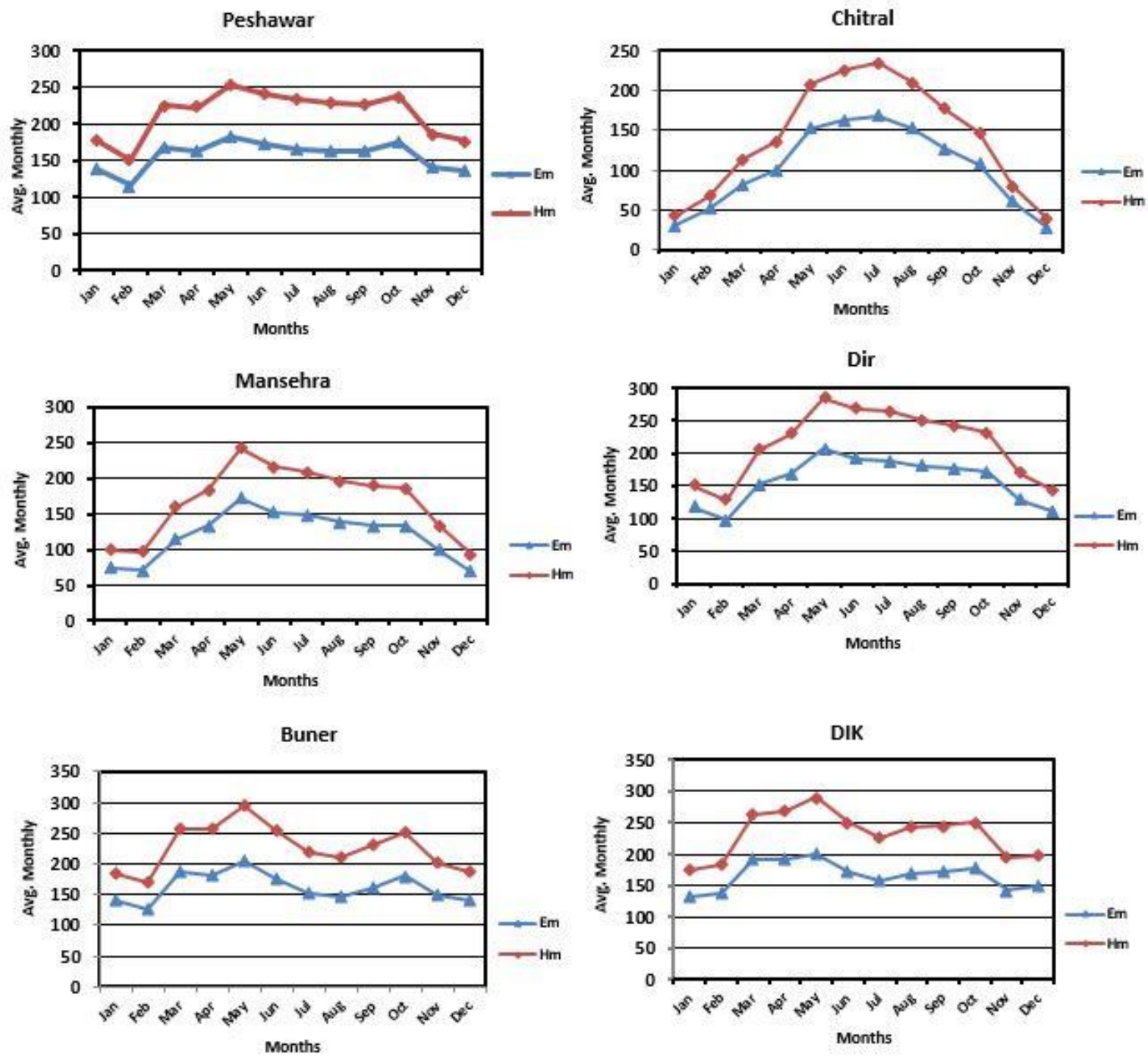

Figure 3. Average monthly electricity production (Em) from the given system $(\mathrm{kWh})$ and average monthly sum of global irradiation $(\mathrm{Hm})$ received by the modules of the given system $\left(\mathrm{kwh} / \mathrm{m}^{2}\right)$ for six districts of Khyber Pakhtunkhwa.

\subsection{Annual PV Estimates}

Figure 4 depicts the estimated electricity production $(\mathrm{kWh})$ per year from a PV system for the six districts of Khyber Pakhtunkhwa, Pakistan. It exhibits the yearly production for a $1 \mathrm{kWp}$ system. Dera 
Ismail Khan (DIK) district shows the highest estimated electricity production followed by Buner, Dir and Peshawar. The lowest estimation is for the Chitral district. Similar results have been discussed for several countries around the world [20,10,22,28-29].

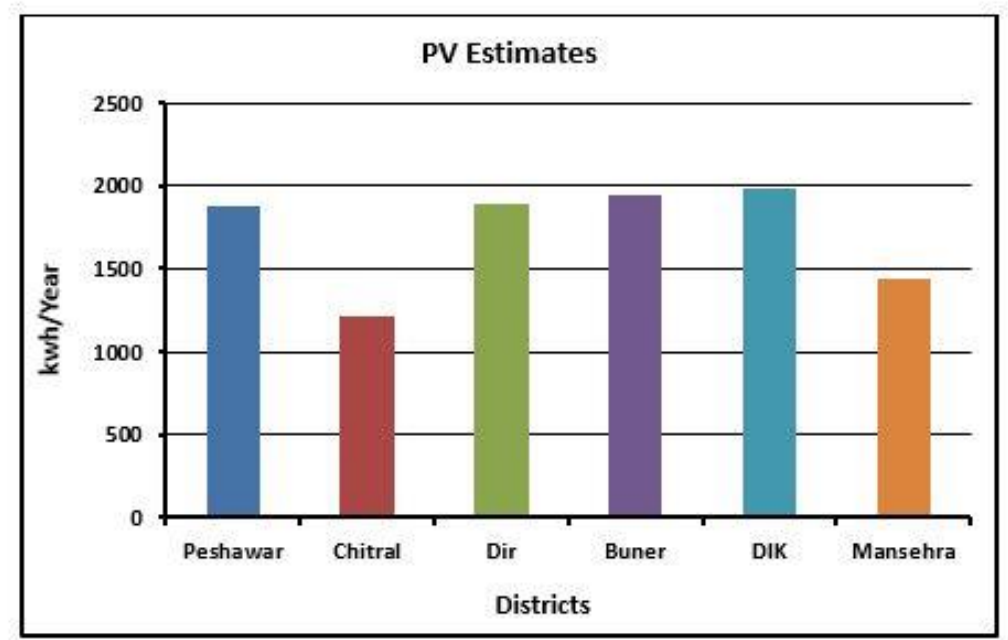

Figure 4. Estimated electricity production $(k W h)$ per year from a PV system for the six districts of Khyber Pakhtunkhwa.

\subsection{Annual Irradiation Estimates}

Figure 5 exhibits the estimated irradiations $\left(\mathrm{kwh} / \mathrm{m}^{2}\right)$ per year for the six districts of Khyber Pakhtunkhwa. Dera Ismail Khan (DIK) district receives the maximum of estimated irradiations followed by Buner, Dir and Peshawar districts. The minimum estimation is for the Chitral district. Annual irradiations are estimated in different countries around the world using various methods for the creation of the graphs and maps [2,8-10,23-24,28]

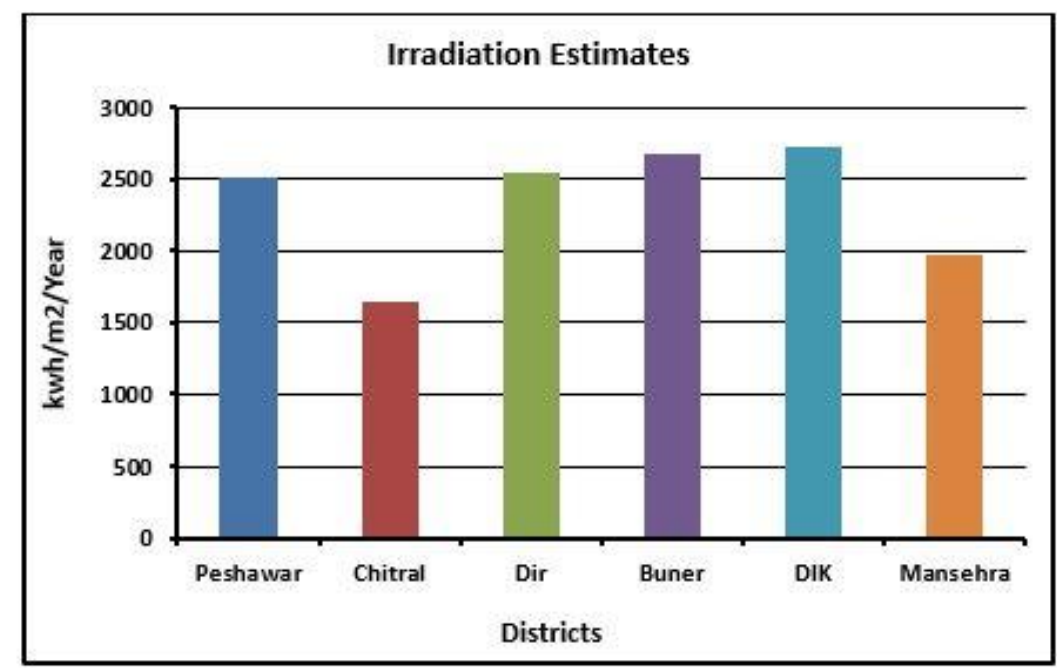

Figure 5. Estimated irradiations $\left(\mathrm{kwh} / \mathrm{m}^{2}\right)$ per year for the six districts of Khyber Pakhtunkhwa.

\section{CONCLUSION}

Renewable energy resources are solutions to the long lasting energy deficiency problems throughout the world including Pakistan, which has the potential of solar energy resources but needs the exploitation for meeting the increasing demand of people. In this paper, the PVGIS module for the estimation of the 
solar electricity generation in six districts of Khyber Pakhtunkhwa Pakistan (such as Dera Ismail Khan (DIK), Chitral, Mansehra, Buner, Peshawar and Dir) was utilized. The PV modules mounting position kept as free standing and inclination as $33^{\circ}$ in the data base, it is found that the daily as well as monthly electricity production and global irradiance for all the districts are maximum in the months of March until October and minimum during January, February, November and December. The results of the estimated electricity production $(\mathrm{kWh})$ and the estimated irradiations $\left(\mathrm{kwh} / \mathrm{m}^{2}\right)$ per year from a PV system for the six districts exhibits that Dera Ismail Khan (DIK) district has highest estimated electricity production as well as the estimated irradiations followed by Buner, Dir and Peshawar districts. It is concluded that PVGIS datasets can be used for the estimation of solar electricity generation and can help in the regional policy-making.

\section{REFERENCES}

[1] Suri, M., Huld, T.A., Dunlop, E.D., PV-GIS: a web-based solar radiation database for the calculation of PV potential in Europe. International Journal of Sustainable Energy, 2005, 24(2), 55-67.

[2] Tarai, R.K., Kale, P., Development of rasterized map using PVGIS for assessment of solar PV energy potential of Odisha, International Journal of Renewable Energy Research, 2016, 6(1), 61-73.

[3] Adnan, S., Khan, A.H., Haider, S., Mahmood, R., Solar energy potential in Pakistan, Journal of renewable and Sustainable Energy, 2012, 4, 032701-032707.

[4] Bakhtiar, F., Ahmed, A., A review of solar energy in Pakistan: Current status and future prospects, Science, Technology and Development, 2017, 36(3), 189-195.

[5] Meghwar, A., Ul-Haq, L., Irshad, N., Techno economic evaluation of off-grid Hybrid solar-wind power system for village Malo Bheel, Tharparkar Sindh Pakistan, American Journal of Energy Research, 2017, 5(2): 28-34.

[6] Ganguli, S., Singh, J., Estimating the Solar Photovoltaic generation potential and possible plant capacity in Patiala, International Journal of Applied Engineering Research, Dindigul, 2010, 1(2), 253-260.

[7] Suri, M., Huld, T.A., Dunlop, E.D., Ossenbrink, H.A., Potential of solar electricity generation in the European Union member states and candidate countries, Solar Energy, 2007, 81, 1295-1305.

[8] Kenny, R.P., Huld, T.A., Iglesias, S., Energy rating of PV modules based on PVGIS irradiance and temperature database, 21st European Photovoltaic Solar Energy Conference, (4-8 September, Dresden, Germany). 2006, 2088-2092.

[9] Suri, M., Huld, T.A., Dunlop, E.D., Albuisson, M., Wald, L., Online data and tools for estimation of solar electricity in Africa: the PVGIS approach, 21st European Photovoltaic Solar Energy Conference and Exhibition (4-8 October Dresden, Germany), 2006, 2623-2626.

[10] Barhdadi, A., Bennis, M., PVGIS Approach for assessing the performances of the first PV grid-connected power plant in Morocco. The African Review of Physics, 2012, 7, 337-344.

[11] Huld, T., Muller, R.W., Gambardella, A., A new solar radiation database for estimating PV performance in Europe and Africa, Solar Energy, 2012, 86(6), 1803-1815.

[12] Ali, A., Khan, T.A., Ahmad, S., Analysis of Climate Data of Khyber Pakhtunkhwa, Pakistan, International Research Journal of Engineering and Technology (IRJET), 2018, 5(5), 4266-4282.

[13] Hussain, S.S., Hussain, S., Hanif, M., Technical Report on Climate Change Scenarios and Possible Adaptation Measures, Chitral and DIK districts of KPK, Pakistan, 2013, DOI: 10.13140/RG.2.1.3123.7849.

[14] ERRA, Report on District Profile-Mansehra. Kamran Printers, Blue Area, Islamabad 2007, http://www.ndma.gov.pk/Publications/District\%20Profile\%20Mansehra.pdf.

[15] Bokhari, SMUH. Pakistan Emergency Situational Analysis District Peshawar, Alhasan Systems Private limited (Islamabad, Pakistan), 2015, ISSN: 2410-8820.

[16] Ali, S., Perveen, A., Qaiser, M., Vegetation Structure, Edaphalogy and Ethnobotany of Mahaban and Malka (District Buner) KPK, Pakistan, Pak. J. Bot, 2015, 47, 15-22.

[17] Martin, M.S., Tristan, C.A., Mediavilla, M.D., Performance indicators form Sun tracking systems: a case study in Spain, Energy and Power Engineering, 2014, 6(9), 292-302.

[18] Belward, A., Bisselink, B., Bódis, K., Brink, A., Dallemand, J.F., de Roo, A., Huld, T., Kayitakire, F., Mayaux, P., Moner-Girona, M., Ossenbrink, H., Pinedo, I., Sint, H., Thielen, J., Szabó, S., Tromboni, U., Willemen, L., JRC Scientific and Technical Report on Renewable energies in Africa 2011, European Union (EUR 25108, Italy), 2011.

[19] Nelson, J., Emmott, C.J.M., Can solar power deliver? Philosophical Transactions of the Royal Society, 2013, $371,1-8$.

[20] Olsan, T., Soucase, B.M., Libra, M., Comparison of predicted and real parameters of PV systems in the Czech Republic and Spain. Agronomy Research, 2018, 16(S1), 1150-1158. 
[21] Pavlovic, TM, Milosavljevic, DD, Pirsl, DS. Simulation of photovoltaic systems electricity generation using homer software in specific locations in Serbia. Thermal Science 2013, 17(2): 333-347.

[22] Dunlop, E.D., Suri, M., Huld, T.A., Photovoltaic potential assessment to support renewable energies growth in 10 EU candidate countries, In: Gottschalg, R. (ed.) Proceedings of the Conference C79 of the Solar Energy Society CREST, Photovoltaic Science, Applications and Technology, Loughborough University (UK), 2003, 3.-4.4., 1007-1016.

[23] Huld, T., PVMAPS: Software tools and data for the estimation of solar radiation and photovoltaic module performance over large geographical areas, Solar Energy, 2017, 1 42, 171-181.

[24] Huld, T.A., Šúri, M., Dunlop, E.D., GIS-based estimation of solar radiation and PV generation in central and eastern Europe on the web, 9th EC-GI\&GIS Workshop (25-27 June, A Coruña, Spain), 2003.

[25] Riaz, M., Ullah, A., Jan, K.U., Prospects and viability of solar energy in Khyber Pakhtunkhwa Pakistan, International Journal of Engineering Research \& Technology (IJERT), 2014, 3(8), 162-167.

[26] Kenny, R.P., Huld, T.A., Iglesias, S., Energy rating of PV modules based on PVGIS irradiance and temperature database, 21st European Photovoltaic Solar Energy Conference (4-8 September Dresden, Germany), 2006, 2088-2092.

[27] Pantic, L.S., Pavlovic, T.M., Milosavljevic, D.D., Mirjanic, D.L., Radonjic, I.S., Radovic, M.K., Electrical energy generation with differently oriented PV modules as Façade elements, Thermal Science, 2015, DOI: 10.2298/tsci150123157p.

[28] Pavlovic, T.M., Milosavljevic, D.D., Pirsl, D.S., Simulation of PV systems electricity generation using HOMER software in specific locations in Serbia, Thermal Science, 2013, 2(17), 333-347.

[29] Cieslak, K., Dragan, P., Comparison of the existing photovoltaic power plant performance simulation in terms of different sources of meteorological data, E3S Web of Conferences, 2018, 49, 00015, https://doi.org/10.1051/e3sconf/20184900015. 